\title{
FATHER-GOD LANGUAGE AND OLD TESTAMENT ALLUSIONS IN JAMES
}

\author{
Esther Yue L. Ng
}

\begin{abstract}
Summary
This article examines three passages in James where God is referred to as $\pi \alpha \tau \eta \rho$ (Father) $(1: 17 ; 1: 27 ; 3: 9)$. In all three cases, it is found that the word is neither a dead metaphor nor a mere title. To the contrary, each use of the word is relevant to what is predicated of God and his works in the immediate context when the OT allusions are identified. In addition, the predominant connotation of the fatherhood of God in James is his creatorship: of the heavenly lights, of orphans and widows, and of human beings in general. However, the fatherhood of God is also used in connection with the redemption of believers in Jesus Christ and has an eschatological dimension. Finally Father-God language in James is used to promote care for the underprivileged and respect for all-the very opposite of overbearing patriarchy.
\end{abstract}

\section{Introduction}

In response to the proliferation of feminist challenges to the propriety of employing the term 'Father' in addressing and referring to God, much has already been written either to explicate its meaning in the Bible or to defend its continued use in the Church today over against gender-inclusive imagery in God-talk. It is interesting, however, that such works rarely, if ever, examine the use of Father-God language in the letter of James. ${ }^{1}$ The present paper is, therefore, a modest attempt to

1 Thus there is no discussion on James at all in the following three books that deal with the issue and examine the biblical evidence beyond the four gospels: Robert Hamerton-Kelly, God the Father: Theology and Patriarchy in the Teaching of Jesus (Philadelphia: Fortress, 1979); John W. Cooper, Our Father in Heaven: Christian Faith and Inclusive Language for God (Grand Rapids: Baker, 1998); Marianne M. Thompson, The Promise of the Father: Jesus and God in the New Testament 
partially fill this lacuna. A key figure often appealed to in the discussion over the NT evidence, especially over the use of $A b b a$ by Jesus, is of course Joachim Jeremias. ${ }^{2}$ Interestingly, while many have questioned (or at least toned down) his view of the novelty of this term as an individual's address to God in prayer in Palestinian Judaism, ${ }^{3}$ some scholars seem to endorse totally his position that Father-God language is used by Jesus (and by the NT writers as well) primarily in eschatological terms to explicate God's faithfulness in redemption rather than God's role as Creator and Provider. ${ }^{4}$ The present paper thus looks at the evidence in James against the backdrop of this redemptionversus-creation discussion as well. Finally, this paper also examines the use of the Old Testament in the letter of James, particularly in the three passages $(1: 17,27 ; 3: 9)$ where the word $\pi \alpha \tau \eta \dot{n}$ (Father) is used in connection with God.

In the following, then, each of the three passages will be examined to see whether and how $\pi \alpha \tau$ in $\rho$ is no mere designation for God, but together with its immediate context plays a significant function by alluding to, or evoking in the minds of readers, ${ }^{5}$ earlier texts, whether

(Louisville: Westminster John Knox, 2000). In the case of G. Schrenk, while he does deal with James 1:17f. in his treatment of God as Father, he omits entirely the other two references in James; see his ' $\pi \alpha \tau$ ' $\rho$ ', in TDNT 5:945-1014 (1013-1014).

2 J. Jeremias, Prayers of Jesus (London: SCM, 1967); idem, New Testament Theology (London: SCM, 1971), 1:61-68.

3 James Barr, 'Abba Isn't "Daddy", JTS n.s. 39 (1988) 28-47; James H. Charlesworth, 'A Caveat on Textual Transmission and the Meaning of Abba: A Study of the Lord's Prayer', in his The Lord's Prayer and Other Prayer Texts from the Greco-Roman Era (Valley Forge: Trinity, 1994), 1-14; Bruce Chilton, 'God as "Father" in the Targumim, in Non-Canonical Literatures of Early Judaism and Primitive Christianity, and in Matthew', in his Judaic Approaches to the Gospels (Atlanta: Scholars Press, 1994), 39-73; Geza Vermes, Jesus the Jew: A Historian's Reading of the Gospels (London: Collins, 1973), 211-13.

4 Thus both Richard Bauckham and Marianne M. Thompson quoted and endorsed Jeremias' statement (New Testament Theology 1:181) that '[i]n Jesus' eyes, being a child of God is not a gift of creation, but an eschatological gift of salvation.' See R. Bauckham, 'The Sonship of the Historical Jesus in Christology', SJT 31 (1978) 243-60 (249); M.M. Thompson, Promise of Father, 32. (For an assessment of Thompson's book, see my review in $E v Q$ [forthcoming].) Other scholars, however, note duly that God's fatherhood is also mentioned in the NT in connection with creation. See, e.g., Donald Guthrie, New Testament Theology (Downers Grove: Inter-Varsity, 1981), 8084; Cooper, Our Father in Heaven, 108, 157, 233.

5 It is difficult to make a distinction between an author's conscious allusion to earlier texts and echoes of earlier texts detected by the reader which the author may not have intended. However, when an author in a particular passage shows a cluster of 'echoes' of one specific earlier text, it strongly suggests that he or she has the earlier text in mind and may be alluding to it in his/her own composition. 
in the OT or in contemporary Judaism. ${ }^{6}$ In so doing we hope to garner some fruits relevant to the two debates mentioned above.

\section{II. 'Father of Lights'}

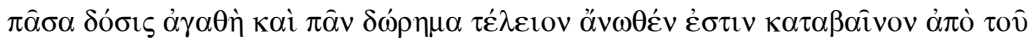

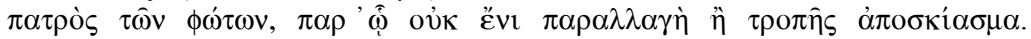

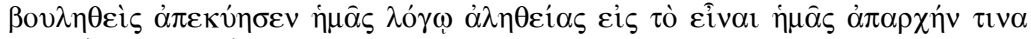
$\tau \hat{\omega} \nu \alpha \hat{\tau} \tau 0 \hat{~ \kappa \tau \iota \sigma \mu \alpha ́ \tau \omega v . ~(J a m e s ~ 1: 17-18, ~ N A-27) ~}$

Every good gift and every perfect gift is from above, and comes down from the Father of lights, with whom there is no variation or shadow of turning. Of His own will He brought us forth by the word of truth, that we might be a kind of firstfruits of His creatures. (James 1:17-18, NKJV)

In commentaries on James, it is generally and rightly pointed out that the expression $\pi \alpha \tau \eta \dot{\rho} \rho \hat{\omega} v \phi \omega \dot{\tau} \omega v$ (Father of Lights) refers to God as Creator of the heavenly lights and that the latter notion is found often in the OT. It is not unusual to find Psalm 136:7 listed among the examples given to support this claim. Nevertheless, the expression per se is not found in the OT nor is it paralleled anywhere else.7 Since God is implied to be the father of rain and dew in Job 38:28, however, calling God the father of inanimate objects in James 1:17 is not without parallel in Judaism. 8

6 This is not to deny that the author could have come under the influence of Greek thought either directly or via Hellenistic Judaism. In fact, it is claimed by James Adamson that 'no NT writer is more Greek than James'. See James B. Adamson, The Epistle of James (NICNT, Grand Rapids: Eerdmans, 1976), 77. The focus of this paper, though, is on Jewish influences on James.

7 While one Greek manuscript of Apoc. Mos. 36 and some versions of T. Ab. 7 have this expression, this is not the predominant reading. See Sophie Laws, A Commentary on the Epistle of James (HNTC, San Francisco: Harper \& Row, 1980), 73. According to Peter H. Davids, the idea of God as the Father of Lights is Jewish both because of the references in the OT and in Judaism on God creating the heavenly lights and because Hellenistic thought apparently did not use $\phi \hat{\omega} s$ to designate heavenly bodies. See his The Epistle of James: A Commentary on the Greek Text (NIGTC, Grand Rapids: Eerdmans, 1982), 87. The latter point, however, is uncertain. For extra-biblical references using the word for the luminaries, see BAGD, s.v. фís, $1 \mathrm{~b}$.

8 Thus Douglas J. Moo, The Letter of James (Pillar New Testament Commentaries, Grand Rapids: Eerdmans, 2000), 78. It has been claimed by Schrenk, however, that in his use of $\pi \alpha \tau$ in with reference to the cosmos, James 'stands in encounter with

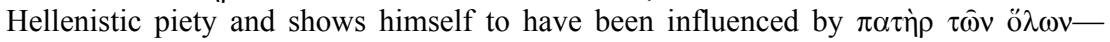
though only in an incidental aphoristic use of this common phrase' (TDNT 6:1013-14). But Schrenk goes on to cite references in Philo for the same conjunction of ideas (God as Father of the кó $\sigma \mu \mathrm{s}$, motif of the unchangeable God linked with changing creation such as stars). 
Some commentators also connect the use of the word $\pi \alpha \tau$ in with the notion of God as the giver of good and perfect gifts in his capacity as Father, one such gift being the luminaries in the sky, and another being the life given to 'us' (v. 18), no matter how one interprets the nature of the life and the scope of the 'we' and 'us'. ${ }^{9}$ However, while the context does imply that good gifts come from God, the primary reason for the 'father' imagery may have more to do with God (like a human father) as the initiator of existence: 10 God is the Father of the lights in the sense of creating them and not giving gifts to them. Moreover,

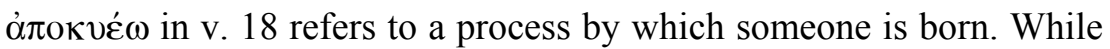
the same word in v. 15 is part of a metaphor of a woman giving birth at full term, it is possible, in view of the 'father' imagery in v. 17, the

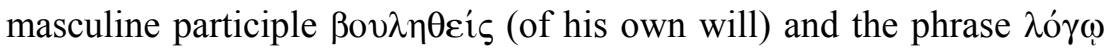
$\dot{\alpha} \lambda \eta \theta \varepsilon i \alpha \varsigma$ (by the word of truth) that the word here has a similar force to $\gamma \varepsilon v v \alpha \dot{\omega} \omega$ and is to be rendered 'begot'. ${ }^{11}$ If so, God is by implication also Father of 'us'. This leads us to consider the nature of the life that has been brought forth and the scope of the 'we' and 'us' in v. 18.

As clearly delineated by Sophie Laws, 12 there are three options in the interpretation of God's gift of life in v. 18, namely, taking it as a reference to (1) the creation of humans in general, (2) the redemption of historical Israel, and (3) the conversion of Christians. Concomitant with the three options are three different interpretations of the 'word of truth' as, respectively, the creative word of Genesis 1:26, the Law, and the gospel. Similarly, there are three corresponding interpretations of the 'first-fruits of his creatures', referring variously to human primacy over the rest of the creation, Israel's special status over other nations, and Christians as a downpayment of a redemptive plan that will eventually encompass all of creation. Since there is no parallel for the idea of the Law as the instrument of Israel's sonship elsewhere and no emphasis on Jewish identity in this letter, we can dismiss the second

9 See, e.g., Davids, James, 88; Moo, James, 79.

10 The various roles of the father in the OT are summed up by Hamerton-Kelly (God the Father, 44-45) as provider and educator, and by Thompson (Promise of the Father, 18 ) as (1) the head of a clan or family giving life and bequeathing an inheritance to his heirs; (2) one who loves and cares for his children; and (3) a figure of authority worthy of obedience and honour.

11 For the view that God here takes on a feminine role, see Ralph P. Martin, James

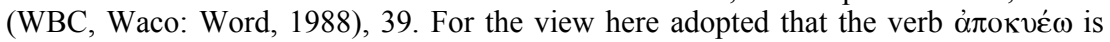
not confined to the female principle and that its use here resembles $\gamma \varepsilon v v \alpha$ ó $\omega$, see

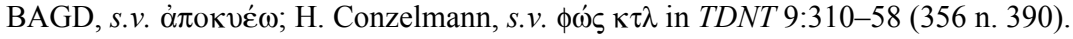

12 Sophie Laws, James, 75-78. 
alternative. 13 The choice is thus between the first and third alternatives. As pointed out by Laws and others, ${ }^{14}$ the first alternative is attractive: the heavenly bodies in v. 17 and the 'creatures' here certainly refer to

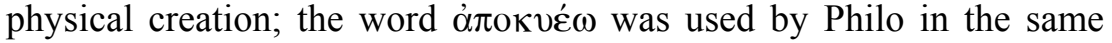
sense. Moreover, it is claimed that there is nothing in the immediate context that prepares one to expect the birth here to be a new birth and the firstfruits to be a new creation. It is not surprising, therefore, that some scholars (e.g. Hort, Blackman, Sidebottom, Laws) are reluctant to rule out this first alternative. Nevertheless, the majority of commentators 15 adopt the third interpretation as more in line with a wider context in the letter and in the NT as well. Thus, it has been pointed out that a spiritual birth is in view here since $\dot{\alpha} \pi$ okvé $\omega$ has already been used in v. 15 in a spiritual (even though negative) sense, and since the received word is 'able to save your souls' in v. 21. Moreover, there are ample examples of the 'word of truth' referring to the gospel as the agent of salvation (2 Cor. 6:7; Eph. 1:13; Col. 1:5; 2 Tim. 2:15), and of Christians as firstfruits in the NT (Rom. 16:5; 1 Cor. 16:15; Rev. 14:4). To this list of arguments one may add also the observation that the twice repeated $\dot{\eta} \mu \hat{\alpha} \varsigma$ (rendered 'us' and 'we') in v. 18 are undoubtedly brethren (vv. 2, 9, 16) who share James' belief in the Lord Jesus Christ $(1: 1 ; 2: 1 ;$ cf. $2: 7)$.

Recently, Donald Verseput has strengthened the argument that v. 18 possesses a soteriological rather than a cosmological significance by drawing our attention to the sequence of Jewish benedictions associated with the recitation of the shema ' in the morning. 16 By the Amoraic period at least, a eulogy to God as the Creator of the Luminaries in the first benediction (preceding the shema') was followed by a second and third benediction (after the shema ${ }^{\prime}$ ) in which God was thanked for his elective love for Israel and his redemption of Israel out of Egypt. That such a general sequence (thanksgiving first for the luminaries then for God's redemption of Israel) predates the rabbinic practice is next supported by references to Mishnah Tamid,

\footnotetext{
13 Ibid.

14 The two alternatives are also carefully weighed in Moo, James, 79-80.

15 Among others, one may cite the following authors: M. Dibelius (James [Hermeneia, Philadelphia: Fortress, 1976], 104-105, and 106 [discussion on $\dot{\alpha} \pi \alpha \rho \chi \dot{]}]$ ), Adamson (James, 76-77), Davids (James, 89), Martin (James, 39-41), Moo (James, 79-80).

16 Donald J. Verseput, 'James 1:17 and the Jewish Morning Prayers', NovT 39 (1997) 177-91.
} 
Josephus and the Dead Sea Scrolls. Verseput then claims that James simply follows Jewish practice when he introduces his crowning reference to the divinely wrought birth of the new community by pointing to the lovingkindness of the "Father of lights" in whom there is no variation nor shadow of change.' 17 Verseput's arguments seem convincing. What he fails to mention, however, is the possibility that this sequence was established on the precedent of Psalm 136 in which God is thanked first for his acts of creation then for his acts during the Exodus. Thus the ninth century Siddur of Amram Gaon cited by Verseput in connection with the first benediction apparently quotes Psalm 136:7:

Blessed are you, O Lord our God, King of the universe, who forms light and creates darkness, who makes peace and creates all things, who in mercy gives light to the earth and to them that dwell thereon, his goodness renews the creation every day continually; as it is said, "to him that makes great lights, for his lovingkindness endures for ever.' Blessed are you, Creator of the luminaries. ${ }^{18}$

Then in the talmudic discussion over the third benediction (often designated 'True and certain' according to its opening words) there was an apparent allusion to Psalm 136:10-15, and perhaps 16-22 as well:

One who recites the shema' must mention the Exodus from Egypt in 'True and certain.' Rabbi says: 'In it one must mention [God's] sovereignty.' Others say: 'In it one must mention the smiting of the first-born and the splitting of the sea.' Rabbi Joshua ben Levi says: 'One must mention all these items and he must say "Rock of Israel and his Redeemer"' (y. Ber. 1:9; cf. B. Ber. 11b). ${ }^{19}$

If the creation-redemption sequence in these benedictions derived from Psalm 136 (Ps. 135, LXX), it is possible that James 1:17-18 too should be interpreted in the light of such a sequence whether or not it reached him indirectly through the morning prayers. In fact, a comparison of these two verses with the psalm shows remarkable parallels in vocabulary and in thought, as is evident in the following table.

17 Ibid., 190.

18 Ibid., 180, n. 10.

19 Ibid., 181. 


\section{James 1}

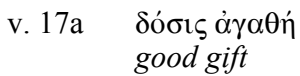

öv $\omega \theta \varepsilon v$

above

$\kappa \alpha \tau \alpha \beta \alpha \hat{\imath} v o s$

coming down

$\pi \alpha \tau \rho o ́ s$

Father

$\tau \hat{\omega} v \phi \omega \dot{\tau} \omega v$

of lights

v. $17 \mathrm{~b}$ no variation or changing shadow

v. 18a

brought forth as first fruits ${ }^{23}$

$\tau \grave{\alpha} \kappa \tau i ́ \sigma \mu \alpha \tau \alpha \alpha$ v่ $\tau \hat{v}$

his creatures [renewed]

\section{Psalm 135 (LXX)}

$\chi \rho \eta \sigma \tau o ́ s$

v. 1

[the Lord] is $\operatorname{good}^{20}$

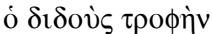

[God] gives food

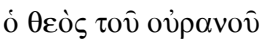

v. 26

God of heaven

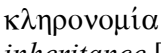

vv. $21 \mathrm{f}$.

inheritance [God gives to Israel]

$\phi \hat{\omega} \tau \alpha \mu \varepsilon \gamma \alpha \dot{\lambda} \lambda \alpha^{21}$

v. 7

great lights [God made]

his love endures forever

$\operatorname{passim}^{22}$

$\pi \rho \omega \tau$ токо

v. 10

firstborn ${ }^{24}$

$\pi \hat{\alpha} \sigma \alpha \sigma \alpha \dot{\alpha} \rho \xi$

v. 25

20 While the Greek words for 'good' are different in the two cases, the underlying Hebrew word טוב is often rendered $\alpha \gamma \alpha \theta$ ó $\varsigma$ elsewhere in the LXX in connection with God's gifts to humans (e.g. Jb. 22:19; Ps. 102:5; 106:9; Is. 55:2).

21 It is noteworthy that the same word $\phi \omega \tilde{\tau} \alpha$ is used in Jas. 1:17 as in Ps. 135:7 (LXX), as apparently this is less common than the word $\phi \omega \sigma \tau \hat{\eta} \rho \varepsilon \varsigma$ for luminaries in the sky. See BAGD, s.v. $\phi \hat{\omega} \varsigma, \phi \omega \sigma \tau \eta \dot{\rho}$.

22 For taking the unchangeability of God to refer primarily to his unwavering lovingkindness in the context of God's gifts, see Verseput, 'Morning Prayers', 190. In a similar vein, Martin (James, 39) thinks that the focus here is on God's nature being unchangeably good and his on his unchangeable attribute of giving only what is good.

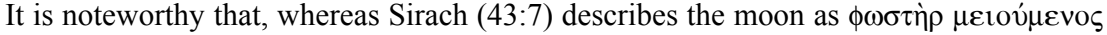

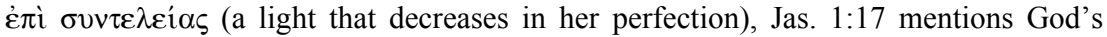
perfect gift in the context of his unchanging character.

23 It is possible that the word $\dot{\alpha} \pi \alpha \rho \chi \eta \dot{~ i n ~ J a s . ~ 1: 18 b ~ d o e s ~ n o t ~ e m p h a s i z e ~ s o ~ m u c h ~ t h e ~}$ chronological sequence as the quality so that it becomes almost the same as $\pi \rho \hat{\omega} \tau$ tos.

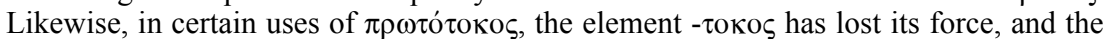
word simply connotes primacy in rank. For these two observations, see BAGD, s.v.

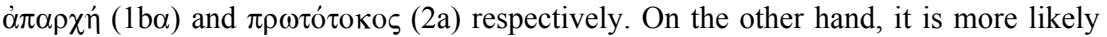
that $\dot{\alpha} \pi \alpha \rho \chi \eta^{\prime}$ in Jas. 1:18 retains the sense of chronological priority (sense of 'downpayment').

24 Though Ps. 135:10 (LXX) does not describe Israel as God's firstborn son, a parallel passage about the smiting of Pharaoh's firstborn explicitly connects this with Israel being God's firstborn (Ex. 4:22-23). Furthermore, though к $\lambda \eta \rho о v o \mu i \alpha$ can refer to possession and property in general, the word is almost always used in secular writings

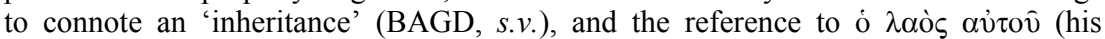
people) in v. 10 also suggests that the 'inheritance' mentioned in vv. 22-23 evokes the imagery of a father-son relationship between God and Israel. For a connection

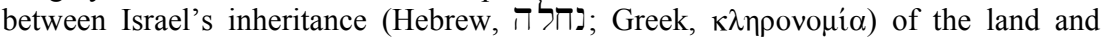
calling God 'Father', see Jr. 3:10. 
If the parallels are real, this would also imply that James had Psalm 136 in mind as he wrote 1:17-18. If so, there is all the reason to see $1: 18 \mathrm{a}$ as referring to the redemption of God's people and $18 \mathrm{~b}$ as hinting at the hope of the eschatological renewal of all creation.

\section{God the Father, the Fatherless and Widows}

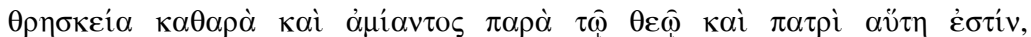

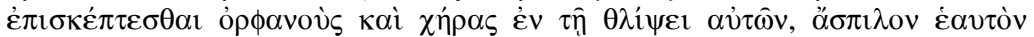

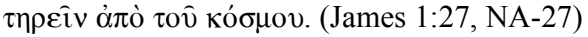

Religion that is pure and undefiled before God, the Father, is this: to care for orphans and widows in their distress, and to keep oneself unstained by the world. (James 1:27, NRSV)

After castigating the one who does not bridle his tongue as a practitioner of a vain ( $\mu \alpha \dot{\tau} \tau \alpha \mathrm{lo})$ ) religion $(\theta \rho \eta \sigma \kappa \varepsilon i ́ \alpha)$ in 1:26, James goes on to describe true religion as characterized by two elements: visiting/caring for orphans and widows in their distress, and keeping oneself unstained from the world. Commentators on James generally see a connection between the first element and the expression 'God the

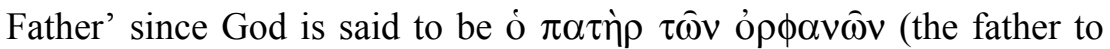

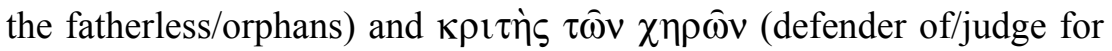
widows in Ps. 67:6 [LXX]), and God's people are repeatedly urged to do the same in the OT (e.g. Ps. 10). Moreover it is usually pointed out that James here follows the prophetic tradition in the OT in denouncing empty words of piety or cultic worship while advocating merciful deeds and upright lives (e.g. Is. 1:11-17; Ho. 6:6; Mi. 6:8). That this verse has a Jewish flavour is also underscored by observing that the

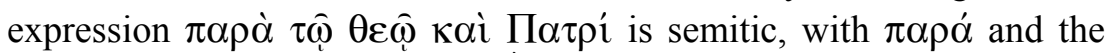
dative rendering the Hebrew לפני (in the presence of). ${ }^{25}$

Such observations are indeed helpful. But it seems to me that James owes even more to OT passages referring to God as Father than outlined above. Besides providing him with the designation of God as Father (to the fatherless) and a concern for orphans and widows, Psalm 67 (LXX) has other themes which recur in James 1:27. Thus James' $\theta \rho \eta \sigma \kappa \varepsilon i \alpha$ (worship of God expressed in religious service or cult) may recall the singing of praises to God in joyful worship in 67:5, $\pi \alpha \rho \grave{\alpha} \tau \hat{\emptyset}$

25 Davids, James, 103; Martin, James, 53. 
$\Theta \varepsilon \hat{\omega}$ evokes the לפניו in the same verse, while the expression $\kappa \alpha \theta \alpha \rho \grave{\alpha} \kappa \alpha i \grave{\alpha} \mu i \alpha v \tau o \varsigma$ (pure and undefiled) coheres well with the

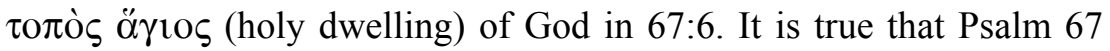
nowhere urges God's people to imitate God in caring for orphans and widows, but the connection has been made already before James's

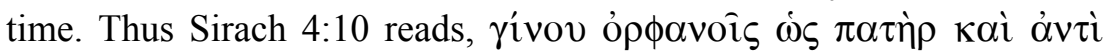


$\sigma \varepsilon \mu \hat{\alpha} \lambda \lambda$ ov $\hat{\eta} \mu \dot{\eta} \tau \eta \rho$ $\sigma o v$ ([b]e a father to the orphans, and be like a husband to their mother; you shall then be like a son of the Most High, and he will love you more than does your mother). In view of the OT's frequent association of orphans, widows with aliens and people in distress or troubled times, two observations may be made on James' statements in 1:27. Firstly, the OT pattern and the lack of emphasis here on the widows and orphans as Christians makes it unlikely that the $\theta \lambda i \psi 1 \varsigma$ (affliction/distress) hints at eschatological tribulation, ${ }^{26}$ even though there is no denying that in this epistle Christians do suffer for their faith (2:6-7). Secondly, this then suggests that the fatherhood of God here in 1:27a (as in the case of the heavenly lights in 1:17) is predicated of the universal creatorship of God.

Nevertheless, just as 1:18 brings in the redemptive dimension of God's fatherhood, 2:27b seems to focus on the special relation between God and his people: they are to be distinguished from the secular world. In this connection, it is instructive to examine another OT passage which adopts 'father' language for God. In Jeremiah 3:19, God longs for a father-son relationship with Israel but is disappointed. This is followed immediately in v. 20 with '[b]ut like a woman unfaithful to her husband, so you have been unfaithful to me, O house of Israel' (NIV). It is possible that in James 1:27 a similar shift in analogy is found. That is to say, God's relationship with Christian believers is both as a father and as a spouse. This claim can be substantiated by two observations. Firstly, in 4:5 God yearns jealously for the purity of his people, and 4:4 describes those who cavort with the world as $\mu \mathrm{o} \chi \alpha \lambda i \delta \varepsilon \varsigma$ (adulterous people [NIV] or unfaithful creatures [RSV]). Secondly, the word $\alpha \mu i \alpha v \tau$ o $\zeta$ sometimes has the connotation of sexual

26 Contra Martin, James, 53; Robert W. Wall, The Community of the Wise: The Letter of James (The NT in Context, Valley Forge: Trinity Press International, 1997), 101. That the word does not always connote eschatological tribulation in the NT is shown in 2 Cor. 8:13 where, judging from the context, it merely refers to difficult circumstances in general. 
purity (used with $\dot{\eta}$ Koí $\tau$ [bed] in Heb. 13:4; and in connection with the $\sigma \tau \varepsilon i \rho \rho$ [barren] in Wis. 3:13). While such qualifiers are absent in James 1:27, the fact that James expands on 1:26-27 in subsequent chapters (e.g. on the tongue, on charitable deeds towards the needy, and on worldliness) makes it at least possible that the adjectives 'pure, undefiled, spotless/unstained' not only have an ethical (not cultic) focus, 27 but may have sexual overtones in an underlying analogy of a marriage relationship.

\section{Blessing the Lord and Father while Cursing Human Beings}

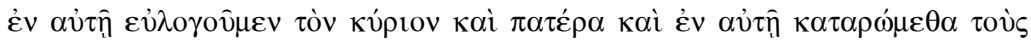

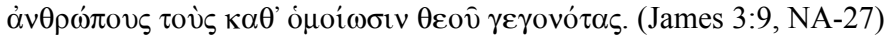

With it [the tongue] we bless the Lord and Father, and with it we curse human beings who are made in the likeness of God. (James 3:9, NAB)

If in the previous passages in James it is unclear whether the notion of God as Father of human beings is specifically connected with his creatorship, James 3:9 seems far less ambiguous. As it is deemed incongruous for the same mouth to bless the Lord and Father on the

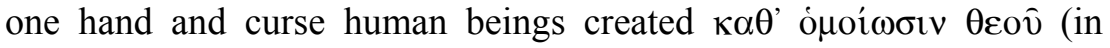
God's image) on the other, this surely implies that creating humans in God's image is integral to his fatherhood 28 and it makes no sense to bless the person (God) and curse his representation (a human) or bless the Father and curse the children. Commentators generally point out that the notion of God creating humans in his image is a familiar one both in the OT (Gn. 1:26; 9:6) and in Judaism (Sir. 17:3; Wis. 2:23; 2 Esd. 8:44). Likewise it is noted that this doctrine was used in Jewish traditions to reject the cursing of men.29 What remains to be demonstrated, however, is how the designation of God as Lord and Father enters the picture, and whether James has in mind specific earlier texts when he penned this passage.

27 Thus Davids (James, 102-103) gives references in Philo (Leg. All. 1.50) and

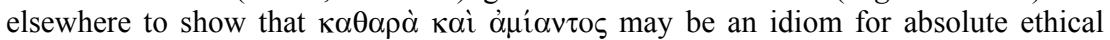
purity.

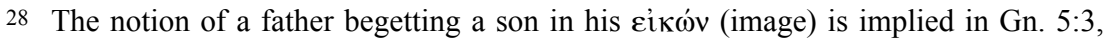

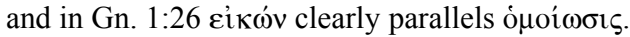

29 Davids (James, 147) cites the following references: Mek. on Ex. 20:26; Gen. Rab. 24:7-8 on Gn. 5:1; Sl. Enoch 44:1; 52:126; Sipra on Lv. 19:18. 
First of all, it has been noted that the terminology ó кúpı $\pi \alpha \tau \eta \dot{\rho}$ is not exactly duplicated in Jewish literature. Thus in Jewish texts which link 'Lord' and 'Father' in invocations there are other elements present in the address to God. Examples of such addresses

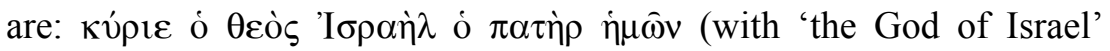
inserted and the addition of 'our' to 'Father' in 1 Ch. 29:10 [LXX]);

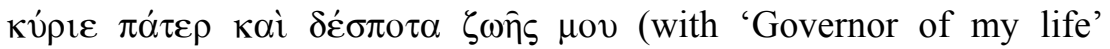

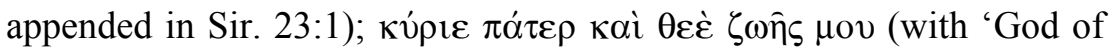
my life' appended in Sir. 23:4). Nevertheless, this at least shows that it is not uncommon to address God as Lord and Father. Also in the first

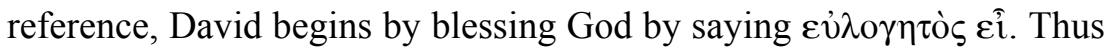
we have a close enough parallel with James 3:9 with regard to blessing the Lord and Father. However, we still need to find other indications of allusions to the OT concerning the creation of humans in the image of God preferably conceived as a father. ${ }^{30}$ Here it seems to me that scholars have generally overlooked the immediate context of Genesis 9:6 in their discussion on James 3:9. It is true that God is nowhere mentioned as a father in Genesis 9, but since it has an unmistakable reference to human beings created in the image of God, it deserves closer scrutiny. Now it is noteworthy that Genesis 8:20-9:17 depicts a scene of worship in which Noah offered sacrifices and God blessed

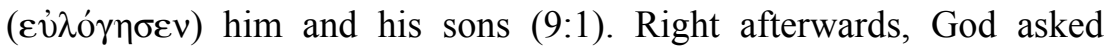
humans to fill the earth and have dominion over it. He promised to put under the power of humans all the wild beasts of the earth, all the birds of the air, all things moving upon the earth, and all the fishes of the sea (v. 2). The reference to the dominion of humans over all such creatures is interestingly paralleled in James 3:7: 'For every species of beast and bird, of reptile and sea creature, can be tamed and has been tamed by the human species' (NRSV). Furthermore, the reference to 'brother

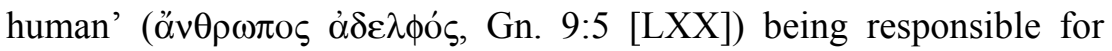
shedding another's blood, coupled with the notion of God making humans in his image, seems to imply that human beings are brothers with the same father.

In addition to seeing such allusions or echoes, we may postulate that Jesus' teaching on bad speech provided some links by which James'

30 In Mal. 2:10, 'have we not one father' parallels 'did not one God create us', and the verse continues to speak of the treachery of every man against his brother. Thus we have here the close association of God's fatherhood with his creatorship and with the brotherhood of God's people. 
observations on the tongue in ch. 3 can be connected to the teaching in Genesis 9.31 Thus James may very well have as his frame of reference Jesus' teaching that anger and insults against one's brother are liable to judgment just as murder is (Mt. 5:21-22). If so, it is an easy step to draw on the reasons against murder in Genesis 9 and apply it to cursing. Furthermore, the incongruity between blessing God and cursing humans (with the analogy of a fig tree yielding olives or grapevine figs) also recalls Jesus' rhetorical question: 'Are grapes gathered from thorns, or figs from thistles?'

\section{Concluding Observations}

In the discussion above, we have seen that the term $\pi \alpha \tau \eta$ is not employed in 1:17 because it is conventional to do so in connection with the heavenly lights. Rather James deliberately uses it to refer to God as their creator. Moreover, this 'father' imagery next leads James to refer to God's begetting children in a spiritual sense, just as Psalm 136 moves from God's creation of the heavenly lights to his redemptive activity in creating Israel at the events associated with the Exodus.

Likewise we have seen that the use of $\pi \alpha \tau \eta \dot{\rho}$ in 1:27 is not gratuitous; it is not a mere, meaningless, appendage to $\theta \varepsilon$ có $\varsigma$ as part of a customary title for God. Rather, its use in connection with the exhortation to care for orphans and widows evokes the imagery of God as the father of orphans and defender of widows in Psalm 68. The dual characterization of true religion as consisting of this aspect and the preservation of oneself unstained from the world may also find its origin in this psalm, possibly supplemented by Jeremiah 3:19.

In James 3:9, too, we noticed that the reference to God as Lord and Father is most meaningful as the verse goes on to emphasize that humans are created in the image of God (with the likely implication that humans are brothers/sisters having God as their common father). It does not seem gratuitous that this verse is situated in a context which has a number of other echoes of the OT passage which forbids the killing of humans made in the image of God (Gn. 9:1-6) and that in

31 Whatever one's views regarding James' knowledge of sayings of the historical Jesus, there is no denying the fact that the epistle shows awareness of teaching incorporated into the Sermon on the Mount. For parallels between Matthew and James, see Martin, James, lxxiv-lxxvi. 
Genesis 9:5 God is said to demand an accounting of the life of the killed person at the hand of the 'brother human'.

Our discussion above is of great relevance to the current debate over Father language for God. For one thing, it is noteworthy that, in contradistinction to other NT writers, notably Paul,32 James never mentions God as the Father of Jesus Christ. Nor does he refer to God as 'Our Father'. ${ }^{33}$ Secondly, the designation of God as Father in James is not a mere name or title. Rather, each use of the word is relevant to what is predicated of him and of his works either in the immediate context or when read intertextually. In other words, the designation of God the Father is no 'dead metaphor' but is a metaphor pregnant with meaning and vitality. 34 Thirdly, the predominant connotation of the fatherhood of God is his creatorship: of the heavenly lights, of orphans and widows, and of human beings in general. ${ }^{35}$ However, fourthly, it is also implied that he is the father of believers in Jesus Christ. Thus the fatherhood of God is used in connection with redemption, as is the case in the OT. Fifthly, this redemptive aspect of the fatherhood of God also has an eschatological dimension, as Christian believers are the 'firstfruits' of a new creation yet to come. This shows that contemporary scholars' tendency to pit redemption against creation in the NT notion of God's fatherhood has no support in James, and I suspect this holds true for certain other parts of the NT as well. Nevertheless, it makes sense to see a gradation of intimacy in God's fatherhood. ${ }^{36}$ While James says nothing about God as the Father of

32 For the pattern of 'father' usage in Paul, see Thompson, Promise of Father, 11819.

33 It is rather unfortunate that some versions (e.g. NIV, NEB) have obscured this difference by adding 'our' before 'Father' or 'Lord' in James 1:27 and 3:9.

34 For the notion of 'dead metaphor' applied to Father-God language in the Gospel of John, see Paul N. Anderson, 'The Having-sent-me Father' in Adele Reinhartz (ed.), God and Father in the Gospel of John, Semeia 85 (1999) 33-57. For contrary views, see M.M. Thompson, 'The Living Father' and Adele Reinhartz, "'And the Word Was Begotten": Divine Epigenesis in the Gospel of John', ibid., 19-31; 83-104.

35 This is also observed by Davids: he comments on 1:26 (James, 103) that 'here as in the other places in James this designation [ $\pi \alpha \tau \dot{\eta} \rho]$ may indicate the universal creatorship of God, that he is just as much father of the one who is slandered or insulted or of the widow who is not helped as of the Christian who professes "true religion".'

36 I owe this notion of gradation to Robert Hamerton-Kelly (God the Father, 81) who shows that "Jesus used the appellation "Father" on three levels of intimacy: "My Father" when he prayed and when he revealed his identity as the son to his disciples; "your Father" when he taught his disciples how to pray to a God who cared for them 
Jesus Christ, it would not be unfair to extrapolate from his use of 'firstfruits' language that God's fatherly redemptive relationship to Christians is distinct from, and more intimate than, his fatherhood over Israel. Certainly God's fatherly relationship to Christians is more intimate than God's fatherhood (conceived as creatorship) over inanimate things and non-human living things, over human beings in general, or orphans and widows in particular, though this does not imply that Christians are exempt from brotherly obligations to unbelievers. Last but not least, our discussion above shows that FatherGod language in James is in no way used to promote an overbearing patriarchy-no matter how patriarchy is defined, or any exploitation and denigration of fellow human beings. The opposite is, in fact, the case. Precisely because God is Father, Christians are to uphold the rights of the underprivileged. Precisely because God is Father, Christians are to show respect to all in their speech and in their actions. Finally, as Christians seek to apply the principle of imitatio Dei implied in the letter, we need to consider whether God's identity as Father even to the lights of the sky suggests that Christians are to be responsible for the environment both on earth and in outer space as well!

with compassion and forgiveness, and assured them of a good time to come; "the Father" when defending his message against doubters and attack.' 